\title{
C32 Zebrafish
}

National Cancer Institute

\section{Source}

National Cancer Institute. C32 Zebrafish. NCI Thesaurus. Code C79958.

A wild-type zebrafish line. 